\title{
Anti-MUM1 Antibody
}

National Cancer Institute

\section{Source}

National Cancer Institute. Anti-MUM1 Antibody. NCI Thesaurus. Code C118800.

Any antibody that recognizes interferon regulatory factor 4 . 